\title{
Molecular genetics of male infertility: A mini-review
}

\author{
Kleber Santiago Freitas e Silva* \\ Biological Sciences Institute, Federal University of Goiás, Brazil
}

\begin{abstract}
Male infertility is a multifactorial condition characterized by the inability of the male to cause pregnancy in a clinically fertile female. Semen quality parameters are used to assess fertility of men and it is an indicative of genetic disorders. Male infertility is mainly influenced by spermatogenic qualitative or quantitative anomalies, ductal obstruction and hypothalamic-pituitary axis dysfunction. Here, we review the molecular genetic basis of male infertility through $\mathrm{X}$ and $\mathrm{Y}$ chromosomes anomalies and genetic polymorphisms. Several X chromosome linked genes, such as AKAP4 and TGIF2LX, affect the ability of a man to have children. Microdeletions in Y chromosome accounts for a large amount of male infertility cases, and the AZF gene is one of the most important and investigated $\mathrm{Y}$ chromosome genes related to infertility. Moreover, clinical studies and biomarker research are able to provide a molecular genetic panel to answer questions and shed different perspectives to a better understanding of the male infertility leading causes.
\end{abstract}

\section{Introduction}

Male infertility is the inability of the male to cause pregnancy in a clinically fertile female [1]. The condition is multifactorial and presents heterogeneous phenotypic features. Genetic factors are responsible for up to $15 \%$ of the male infertility cases and may be even higher for quantitative infertility defects such as azoospermia [2]. Genetic factors may be involved in idiopathic male infertility, which accounts for $40 \%$ of cases, even though the related genes remain unknown [3]. In addition, male infertility is the leading cause of infertility in $20-70 \%$ of couples [4]. Identifying genetic anomalies plays an essential role in the success of assisted reproductive treatments.

Semen quality parameters (Figure 1) established by World Health Organization (WHO) is used to assess fertility of men and it is an

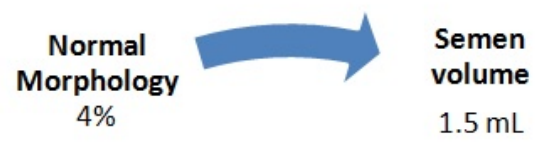

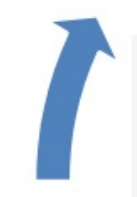

Vitality $55 \%$
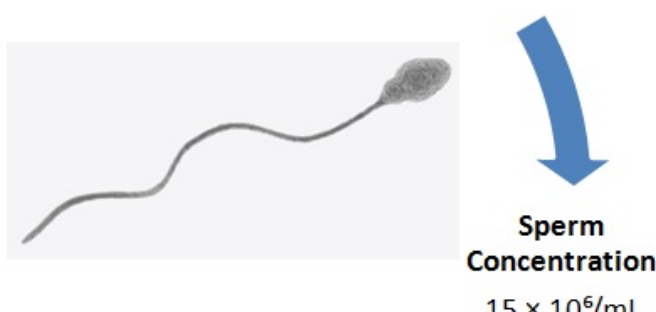

$15 \times 10^{6} / \mathrm{mL}$

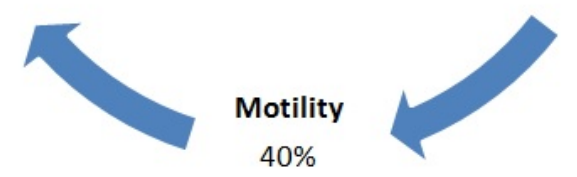

Figure 1. Infertility is a global health issue. The inability to conceive children leads to social, psychiatric and severe medical consequences. WHO has standardized a method for the evaluation of human semen based on values for normal fertility [1]

indicative of genetic disorders. Male infertility can be classified into four distinct categories: spermatogenic qualitative or quantitative anomalies, ductal obstruction and hypothalamic-pituitary axis dysfunction. The onset of any of those aetiological issues can be driven by a genetic cause [5]. The most common genetic causes of male infertility include sex chromosome aneuploidies [6], Y chromosome microdeletions [7], gene polymorphisms [8] and congenital absence of the vas deferens [9] among other factors.

\section{$\mathrm{X}$ chromosome anomalies leading to male infertility}

Klinefelter syndrome is one of the most frequent cytogenetic anomalies found in infertile men [10]. The most frequent type of karyotype present in men with Klinefelter syndrome is 47, XXY. The syndrome can also be related to mosaicism [11], higher number of X chromosomes such as 48, XXXY; 48, XXYY or even 49, XXXXY and structurally abnormalities in sex chromosomes [12]. Notably, Klinefelter syndrome men present hypogonadism, azoospermia, small testes, erectile dysfunction and higher gonadotropin levels compared to normal and fertile men [13]. Patients with XX male syndrome (46, $\mathrm{XX}$ ) are less common than Klinefelter syndrome [14]. Uneven crossing over between $\mathrm{X}$ and $\mathrm{Y}$ chromosomes may result in an additional $\mathrm{X}$ chromosome bearing the SRY gene through a translocation process $[15,16]$. Patients with XX male syndrome are infertile and may develop male external genitalia, micropenis, hypospadia and cryptorchidism [14]. Klinefelter syndrome is easily detected through conventional cytogenetic analysis but $\mathrm{XX}$ male syndrome requires molecular cytogenetic with SRY probe to be performed.

Several X chromosome genes function in testicular tissue and might be related to different levels of male in fertility. The AKAP4 gene, for example, code for proteins that interact with protein kinase A (PKA) in the sperm flagellum. PKA guarantees energy supply in spermatozoids and AKAP4 is requested for sperm motility. AKAP4

${ }^{\star}$ Correspondence to: Kleber Santiago Freitas e Silva, Biological Sciences Institute, Federal University of Goiás, Brazil, E-mail: smallbinho@hotmail.com

Received: July 07, 2018; Accepted: July 27, 2018; Published: July 30, 2018 
has been investigated in infertile men [17] and it was reported an infertile man with normal sperm count and total sperm immobility in which dysplasia of the fibrous sheath were promoted by Akap4 gene deletions [18]. Another gene, TGIF2LX (transforming growth factorbeta-induced factor 2 like, $\mathrm{X}$-linked) is located on $\mathrm{X}$ chromosome, is homologous with a region on the $\mathrm{Y}$ chromosome and is expressed in the testicular tissue. TGIF2LX is required for normal cellular proliferation levels and for differentiation processes during spermatogenesis. This gene is altered in patients with Turner syndrome and may also be related to severe cases of infertility [19].

\section{Y chromosome anomalies leading to male infertility}

It has been long known that essential genes on the long arm of the $\mathrm{Y}$ chromosome is required for normal spermatogenesis [20]. The AZF gene is one of the most investigated $\mathrm{Y}$ chromosome genes related to infertility. The AZF chromosome region contains repeated homologous sequences prone to undergo deletion, duplication or translocation through homologous recombination [21]. The complete deletion of AZF genes in the population is infrequent, but on the other hand, around $10 \%$ of patients with idiopathic infertility show AZF complete or partial deletions [22]. Infertile patients with AZF deletions but showing at least minimal levels of spermatogenesis could have children through sperm aspiration followed by intracytoplasmic sperm injection. Unfortunately, the AZF deletion is inherited by the male offspring.

The PAR (pseudo autosomal regions) genes of the $\mathrm{Y}$ chromosome show regions of homology between the sexes chromosomes $\mathrm{X}$ and Y. Several studies show relation between PARs deletion and male infertility [23], higher chances of producing sex chromosome aneuploidy in sperm cells [24] and the occurrence of Turner syndrome and Klinefelter syndrome [25]. The non-homologous region of the $\mathrm{Y}$ chromosome contains genes that code for protein belonging to the MSY (male specific region) family genes. They control the development of gonads and spermatogenesis, thus, they are potentially involved in male infertility causes.

Evidences show that several genes on the Y chromosome affect spermatogenesis [20], sperm maturation, motility and viability [26]. The ZFY gene (zinc finger Y linked protein) is locate on chromosome $\mathrm{Y}$ and has a role in spermatogenesis and processes of microdeletion of Y chromosome in the ZFY region could affect men fertility [27]. USP9Y is related to the development of germ cells in males [28] and it has been show that knock out of this gene in the mice leads to sterility due to spermatogenesis arrest [29]. The PRY gene on Y chromosome encodes for a tyrosine phosphatase, which is overexpressed in males with defective spermatogenesis. PRY takes part in the regulation of apoptosis in order to retrieve abnormal sperm cells [26].

\section{Gene polymorphisms leading to male infertility}

A polymorphic gene has multiple alleles at a locus with at least $1 \%$ of frequency in a given population. Several studies have demonstrated the solid influence of polymorphisms on a large variety of genes, leading to male infertility. For example, the blood-testis barrier is related to testicular damage and male infertility. The regulation of the bloodtestis barrier function lies on several cytokines such as the transforming growth factor beta 3 (TGF- $\beta 3$ ) and the tumor necrosis factor (TNF- $\alpha$ ). A large study involving 846 patients showed the association between TGF- $\beta 3$ and TNF- $\alpha$ gene polymorphisms and male infertility [30]. Other variants of TNF- $\alpha$ have also been subjected to investigation regarding the infertility [31].
Polymorphism of the Cytochrome P450 1A1 (CYP1A1) gene and the risk for idiopathic male infertility has also been investigated. CYP1A1 regulates phase I metabolism of polycyclic aromatic hydrocarbons that can be harmful to the homeostasis of mammal's reproductive system [32]. A large variety of studies have investigated the relationship between CYP1A1 polymorphisms and infertility in Chinese [33-35], Brazilian [36], Indian [37], Turkish [38] and German [40] populations. Another risk factor for male infertility is the polymorphism of the methylenetetrahydrofolate reductase (MTHFR) gene. The enzyme product of the MTHFR gene regulates folate metabolism and is related do DNA methylation. A large-scale study with 5,575 infertile patients showed statistically significant relationship between MTHFR polymorphism and male infertility [41]. The infertility led by abnormal activity of the MTHFR enzyme may be due to abnormal methylation of sperm DNA.

\section{Concluding remarks}

Over the last decade, molecular genetic techniques have improved diagnosis and treatment of male infertility, a complex and multifactorial condition that affects men around the globe. The genetic basis for the male infertility ranges from single nucleotide polymorphism to a whole chromosome deletion. Diagnostic interpretation of mutations and variability is an arduous process and limits the identification of genetic aetiology of male infertility. X-chromosomal anomalies, Y chromosome microdeletions and genetic polymorphism outline the sperm parameters defects found in infertile men such as sperm motility and viability. Clinical studies, karyotype investigation and biomarker research will provide a molecular genetic panel to answer questions and shed different perspectives to a better understanding of the male infertility leading causes.

\section{Declaration}

The author declares no financial support was sought in this project and there is no conflicts of interest.

\section{References}

1. Evgeni E, Lymberopoulos G, Touloupidis S, Asimakopoulos B (2015) Sperm nuclear DNA fragmentation and its association with semen quality in Greek men. Andrologia 47: 1166-1174. [Crossref]

2. Agarwal A, Mulgund A, Hamada A, Chyatte MR (2015) A unique view on male infertility around the globe. Reprod Biol Endocrinol 13: 37. [Crossref]

3. Cooper TG, Noonan E, von Eckardstein S, Auger J, Baker HW, et al. (2010) World Health Organization reference values for human semen characteristics. Hum Reprod Update 16: 231-245. [Crossref]

4. Rutstein SO, Shah IH (2004) Infecundity, infertility, and childlessness in developing countries. DHS comparative reports no. 9. Geneva: World Health Organization.

5. Tournaye H, Krausz C, Oates RD (2017) Novel concepts in the aetiology of male reproductive impairment. Lancet Diabetes Endocrinol 5: 544-553. [Crossref]

6. Röpke A, Tüttelmann F (2017) Mechanisms in endocrinology: Aberrations of the $\mathrm{X}$ chromosome as cause of male infertility. Eur J Endocrinol 177: R249-249R259. [Crossref]

7. GholamiD, Jafari-Ghahfarokhi H, Nemati-Dehkordi M, Teimori H(2017)Y chromosome microdeletions frequency in idiopathic azoospermia, oligoasthenozoospermia, and oligospermia. Int J Reprod Biomed 11: 703-712. [Crossref]

8. Jaiswal D, Trivedi S, Agrawal NK, Singh K (2014) Association of the gonadotrophinregulated testicular RNA helicase gene polymorphism with human male infertility. Andrologia 46: 1063-1066. [Crossref]

9. Yang X, Sun Q, Yuan P, Liang H, Wu X, et al. (2015) Novel mutations and polymorphisms in the CFTR gene associated with three subtypes of congenital absence of vas deferens. Fertil Steril 104: 1268-1275. [Crossref] 
10. Van Assche E, Bonduelle M, Tournaye H, Joris H, Verheyen G, et al. (1996) Cytogenetics of infertile men. Hum Reprod 11 Suppl 4: 1-24. [Crossref]

11. Gekas J, Thepot F, Turleau C, Siffroi JP, Dadoune JP, et al. (2001) Chromosomal factors of infertility in candidate couples for ICSI: an equal risk of constitutional aberrations in women and men. Hum Reprod 16: 82-90. [Crossref]

12. Bojesen A, Juul S, Gravholt CH (2003) Prenatal and postnatal prevalence of Klinefelter syndrome: A national registry study. J Clin Endocrinol Metab 88: 622-626. [Crossref]

13. Bonomi M, Rochira V, Pasquali D, et al. (2017) Klinefelter syndrome (KS): genetics, clinical phenotype and hypogonadism. J Endocrinol Invest 40: 123-134. [Crossref]

14. Vorona E, Zitzmann M, Gromoll J, Schüring A, Nieschlag E (2007) Clinical, endocrinological, and epigenetic features of the 46,XX male syndrome, compared with 47,XXY klinefelter patients. J Clin Endocrinol Metab 92: 3458-3465. [Crossref]

15. Rigola MA, Carrera M, Ribas I, Egozcue J, Miró R, et al. (2002) A comparative genomic hybridization study in a 46,XX male. Fertil Steril 78: 186-188. [Crossref]

16. Weil D, Wang I, Dietrich A, Poustka A, Weissenbach J, Petit C (1994) Highly homologous loci on the $\mathrm{X}$ and $\mathrm{Y}$ chromosomes are hotspots for ectopic recombinations leading to XX maleness. Nature Genetics 7: 414-419. [Crossref]

17. Baccetti B, Collodel G, Estenoz M, Manca D, Moretti E, et al. (2005) Gene deletions in an infertile man with sperm fibrous sheath dysplasia. Hum Reprod 20: 2790-2794. [Crossref]

18. Rahamim L, Almog T, Yao Z, Seger R, Naor Z (2016) A-Kinase Anchoring Protein 4 (AKAP4) is an ERK1/2 substrate and a switch molecule between cAMP/PKA and PKC/ERK1/2 in human spermatozoa. Sci Rep 6: 37922.

19. Stouffs K, Lissens W (2012) X chromosomal mutations and spermatogenic failure. Biochim Biophys Acta 1822: 1864-1872. [Crossref]

20. Tiepolo L, and Zuffardi O (1976) Localization of factors controlling spermatogenesis in the nonfluorescent portion of the human Y chromosome long arm. Hum Genet 34: 119-124.

21. Skaletsky H, Kuroda-Kawaguchi T, Minx PJ, Cordum HS, Hillier L, et al. (2003) The male-specific region of the human $\mathrm{Y}$ chromosome is a mosaic of discrete sequence classes. Nature 423: 825-837. [Crossref]

22. Lo Giacco D, Chianese C, Sánchez-Curbelo J, Bassas L, Ruiz P, et al. (2014) Clinical relevance of Y-linked CNV screening in male infertility: new insights based on the 8-year experience of a diagnostic genetic laboratory. Eur J Hum Genet 22: 754-761. [Crossref]

23. Mohandas TK, Speed RM, Passage MB, Yen PH, Chandley AC, et al (1992) Role of the pseudoautosomal region in sex-chromosome pairing during male meiosis: meiotic studies in a man with a deletion of distal Xp. Am J Hum Genet 51: 526-533.

24. Gabriel-Robez O, Rumpler Y, Ratomponirina C, Petit C, Levilliers J, Croquette MF, Couturier J (1990) Deletion of the pseudoautosomal region and lack of sex chromosome pairing at pachytene in two infertile men carrying an $\mathrm{X} ; \mathrm{Y}$ translocation. Cytogenet Cell Genet 54: 38-42. [Crossref]

25. Hassold TJ, Sherman SL, Pettay D, Page DC, Jacobs PA (1991) XY chromosome nondisjunction in man is associated with diminished recombination in the pseudoautosomal region. Am J Hum Genet 49: 253-260. [Crossref]
26. Repping S, van Daalen SK, Korver CM, Brown LG, Marszalek JD, et al. (2004) A family of human $\mathrm{Y}$ chromosomes has dispersed throughout northern Eurasia despite a $1.8-\mathrm{Mb}$ deletion in the azoospermia factor c region. Genomics 83: 1046-1052. [Crossref]

27. Dhanoa JK, Mukhopadhyay CS, Arora JS (2016) Y-chromosomal genes affecting male fertility: A review. Vet World 9: 783-791. [Crossref]

28. Lee KH, Song GJ, Kang IS, Kim SW, Paick JS, et al. (2003) Ubiquitin-specific protease activity of USP9Y, a male infertility gene on the Y chromosome. Reprod Fertil Dev 15: 129-133. [Crossref]

29. Kishi K, Uchida A, Takase HM, Suzuki H, Kurohmaru M, et al. (2017) Spermatogonia deubiquitinase USP9X is essential for proper spermatogenesis in mice. Reproduction 154: 135-143. [Crossref]

30. Drozdzik M, Kaczmarek M, Malinowski D, Bros U, Kazienko A, et al. (2015) TGFß3 (TGFB3) polymorphism is associated with male infertility. Sci Rep 5: 17151. [Crossref]

31. Mostafa T, Taymour M (2016) TNF- $\alpha-308$ polymorphisms and male infertility risk: A meta-analysis and systematic review. $J$ Adv Res 7: 185-192. [Crossref]

32. McManus ME, Burgess WM, Veronese ME, Huggett A, Quattrochi LC, Tukey RH (1990) Metabolism of 2-acetylaminofluorene and benzo(a)pyrene and activation of food-derived heterocyclic amine mutagens by human cytochromes P-450. Cancer Res 50: 3367-3376. [Crossref]

33. Chen W, Kang X, Huang Z, Wei Y, Pan Y (2010) CYP1A1 gene polymorphism in oligozoospermic infertile patients of Zhuang population in Guangxi area. Guangdong Med J 13: 1669-1671.

34. Lu N, Wu B, Xia Y, Wang W, Gu A, et al. (2008) Polymorphisms in CYP1A1 gene are associated with male infertility in a Chinese population. Int $J$ Androl 31: 527-533. [Crossref]

35. Peng L, Wang G, Jiao H, Li Y, Dang J (2012) CYP1A1 gene (rs4646903) polymorphism in infertile patients in Ningxia area. J Ningxia Med Univ 03: 208-210.

36. Barbosa AM, de Souza SR, Frare AB, et al. (2016) Association of CYP1A1 (cytochrome P450) MspI polymorphism in women with endometriosis. Genet Mol Res 15. [Crossref]

37. Vani GT, Mukesh N, Siva Prasad B, Rama Devi P, Hema Prasad M, et al. (2009) Association of CYP1A1*2A polymorphism with male infertility in Indian population. Clin Chim Acta 410: 43-47. [Crossref]

38. Aydos SE, Taspinar M, Sunguroglu A, Aydos K (2009) Association of CYP1A1 and glutathione S-transferase polymorphisms with male factor infertility. Fertil Steril 92 : 541-547. [Crossref]

39. Fritsche E, Schuppe HC, Döhr O, Ruzicka T, Gleichmann E, et al. (1998) Increased frequencies of cytochrome P4501A1 polymorphisms in infertile men. Andrologia 30 : 125-128. [Crossref]

40. Kobayashi H, Sato A, Otsu E, Hiura H, Tomatsu C, et al. (2007) Aberrant DNA methylation of imprinted loci in sperm from oligospermic patients. Hum Mol Genet 16: 2542-2551. [Crossref]

41. Gong M, Dong W, He T, Shi Z, Huang G, et al. (2015) MTHFR 677C $>$ T polymorphism increases the male infertility risk: a meta-analysis involving 26 studies. PLoS One 10: e0121147. [Crossref]

Copyright: (C)2018 Freitas e Silva KS. This is an open-access article distributed under the terms of the Creative Commons Attribution License, which permits unrestricted use, distribution, and reproduction in any medium, provided the original author and source are credited. 